PRICING LIVES 



\section{Pricing Lives}

\section{Guideposts for \\ a Safer Society}

\section{W. Kip Viscusi}

PRINCETON UNIVERSITY PRESS

PRINCETON AND OXFORD 
Copyright $(2018$ by Princeton University Press

Published by Princeton University Press,

41 William Street, Princeton, New Jersey 08540

In the United Kingdom: Princeton University Press,

6 Oxford Street, Woodstock, Oxfordshire OX20 ITR

press.princeton.edu

Jacket graphics and design by Amanda Weiss

All Rights Reserved

Library of Congress Control Number: 2018932156

ISBN 978-0-691-17921-6

British Library Cataloging-in-Publication Data is available

This book has been composed in Adobe Text Pro and Gotham

Printed on acid-free paper. $\infty$

Printed in the United States of America

$\begin{array}{llllllllll}10 & 9 & 8 & 7 & 6 & 5 & 4 & 3 & 2 & 1\end{array}$ 
For Robert J. Viscusi 
